\title{
Wendigo Psychosis
}

\author{
Michalina Kolan BCDEF ${ }^{1}$, Kamil Leis ABCDEF ${ }^{1}$ https://orcid.org/0000-0003-3022-5545, \\ Aleksandra Baska вCDEF ${ }^{1}$, Jakub Kazik BCDEF ${ }^{1}$, Przemysław Gałązka всDEF ${ }^{2}$ \\ https://orcid.org/0000-0002-8227-8350
}
1 Faculty of Medicine, Ludwik Rydygier Collegium Medicum in Bydgoszcz, Nicolaus Copernicus University in Toruń, Poland
2 Department of General and Oncological Surgery for Children and Adolescents, Antoni Jurasz University Hospital No. 1 in Bydgoszcz, Ludwik Rydygier Collegium Medicum in Bydgoszcz, Nicolaus Copernicus University in Toruń, Poland

\begin{abstract}
Introduction: Wendigo psychosis is considered an endemic psychiatric disorder associated with culture. It manifests through compulsive, strong attacks of cannibalistic behaviors. It mainly concerns Algonquian: Cree tribes and people living in the Northern Ojibwa area.

Material and methods: In our article, we have collected available publications on Wendigo's psychosis. This area included Internet databases: PubMed and Google Scholar, from the first reports on the disease to the latest information. Due to culturebound syndromes and the rarity of occurrence in the present time at work, we focused not only on symptoms, treatment or diagnosis, but also on historical and ethnographic features.

Discussion: The first remarks on this disorder derive from the Powhatan dictionary which was used by the Algonquian tribe. In the 1960 s there were 70 cases of the disease, but the available epidemiologic data is poor. There are many legends about the mythical creature Wendigo and its likeness is repeatedly used in popular culture. Most of the symptoms exhibited by those suffering from this dysfunction is related to famine and chronic loneliness, e.g. apathy, neurosis.

Summary: The treatment of the psychosis in the past was based on folk beliefs, as well as homicide. Modern medicine offers a wide spectrum of antipsychotic drugs whose use is focused on the elimination of side effects. Pharmacotherapy consists in administering to the sick drugs from the group of benzodiazepines or antipsychotic agents of both the first and the second generation.
\end{abstract}

Keywords: Wendigo psychosis, cannibalism, culture-bound syndromes

\section{Streszczenie}

Wstęp: Psychoza Wendigo uznana jest za zaburzenie stanu psychicznego uwarunkowane kulturowo, występujące endemicznie. Powiązane jest z kompulsywnymi, silnymi atakami zachowań kanibalistycznych. Obserwowane jest głównie u Algonikan: plemion Cree oraz ludzi, zamieszkujących tereny Północnej Ojibwy.

Materiał i metoda: W naszym artykule zebraliśmy dostępne publikacje dotyczące psychozy Wendigo. Obszar ten obejmowały bazy internetowe: PubMed oraz Google Scholar, począwszy od pierwszych doniesień na temat schorzenia, aż do najnowszych informacji. Z racji uwarunkowania kulturowego oraz rzadkości występowania w czasach obecnych w pracy skupiliśmy się oprócz objawów, leczenia czy diagnostyki także na rysie historycznym oraz etnograficznym.

Dyskusja: Pierwsze doniesienia na temat tej choroby pochodzą ze słownika Powhatan, którego używało plemię Algonkian. W latach 60 XX wieku odnotowano 70 przypadków zachorowań, jednakże dostępne dane epidemiologiczne są dosyć ubogie. Na temat mitycznego stworzenia Wendigo powstało wiele legend, a jego wizerunek wykorzystywany jest niejednokrotnie w kulturze popularnej. Większość objawów które przejawiają osoby cierpiące na to schorzenie związane jest z doskwierającym głodem i przewlekłą samotnością np. apatia czy nerwica.

Wnioski: W przeszłości leczenie psychoz opierało się na ludowych przekonaniach, tudzież na morderstwie chorych. Dzisiaj medycyna oferuje szerokie spektrum leków przeciwpsychotycznych, przy stosowaniu których istotne jest niwelowanie działań niepożądanych. Farmakoterapia polega na podawaniu chorym leków z grupy benzodiazepin bądź środków przeciwpsychotycznych zarówno pierwszej jak i drugiej generacji. 
Słowa kluczowe: psychoza Wendigo, kanibalizm, zespoły uwarunkowane kulturowo

\section{Introduction}

Wendigo or Windigo psychosis is a psychiatric culture-bound disorder manifesting mainly by cannibalistic acts, and fear associated with their commitment [1]. According to the Algonquian beliefs, the monster arises from the possession of a met human being; such a person feels an overwhelming urge to eat another human being [2]. The dysfunction concerns the Algonquian natives, Northern Ojibwa and the Cree tribe. There are no known cases of this psychosis in the other parts of the world. The impulse usually arises as a result of the stress accompanying the famine-stricken during the winter period [3].

\section{History and myths}

Algonquian tribe may be distinguished from the aboriginal people of the Northern America. Among their beliefs and culture there is a mysterious figure of Wendigo [4]. The men from the subarctic territory of the continent were hunting alone for the most of the year, practicing their skills that were crucial for survival. Every day they delved into their spirituality and devotion. They lived with their families and met other inhabitants only for a brief episode of summertime. During numerous locals' confrontations, including their hunting competition, a paradox occurred; the stronger the warrior was, the more scared the tribe became and subsequently there were assassinations of the strongest individuals [5].

In the language of aboriginal people wendigo means a fool or a cannibal monster [6]. It is identified with an enormous iceberg, a snow monster or an ice monster. It is characteristic of a permanent hunger and consequent multiple acts of cannibalism [3]. According to the traditional storytelling, it is described as a grotesque monster, huge and slim at the same time with an odor of a rotting body. Its approach is spelled by frost and roaring wind, and the consumption of a human being does not provide a feeling of satiety. In the novel of Basil Johnston The Manitous: The Supernatural World of the Ojibway, the significant features of Wendigo are indifference to pain and to others' suffering. In a span of time the imagination of Wendigo has evolved; from the perception of the physical monster to a mental illness affecting people. More and more often, the primary image of the disease is marginalized, left among legends and myths. The image of the figure is repeatedly used in popular science and entertainment [7].

The literature differentiates three various categories of Wendigo. The first one is a quite surrealistic vision of a superhuman monster in the primary or the secondary form. The next imagination tells that a human spirit becomes possessed by a cannibalistic being [3]. The possessed human being was lost and could fulfill only its wishes (except for possessed shamans with supernatural powers) [5]. The last one and the most realistic one finds Wendigo as a kind of culturally and endemically conditioned psychosis, related to compulsive acts of cannibalism [3].

The first reports concerning Wendigo were found in the Powhatan dictionary, which is a language of Eastern Algonquian used by members of the Powhatan confederation [8]. In the criticism of Gerald from 1904 the mythical creature was presented as a giant carnivorous man. The first reported case of the Wendigo psychosis is dated on 1634-1635 and refers to an anorectic Quebec Montagnais suspected of cannibalistic behaviors. The next rumors come from 1660-1661 and concern a Jesuit missionary Lac Saint Jean and his non-typical fixation about human flesh. Many references suggest that Windigo is not an individual, but it should be considered as multiple embodiment [6].

The most known cases of the dysfunction concern Swift Runner and Jack Fiddler. In the 20th century the incidence rate of Wendigo psychosis was suddenly decreased as a result of following more developed civilizations' patterns by Northern Algonquian.

The hunter Plains Cree from Alberty, known as Swift Runner, is held as a classical case of Wendigo psychosis. During the winter season in 1878 a series of tragic events took place. Due to the permanent hunger, the oldest descendant of the trapper from Alberty died. The next day a mother and five children, being close to a food repository in Hudson's Bay, were suddenly attacked. The culprit was a father and a husband, Swift Runner. The murder was committed for the cannibalistic purpose. Because of the murder background, which was a short distance to the food supply and losing all members of the family, the man was diagnosed with Wendigo psychosis. He was sentenced to death in Fort Saskatchewan [2].

Jack Fiddler was an Oji-Cree boss and a medicine related professional; he was believed to have supernatural powers of defeating Wendigo. It often resulted in a death of the person suffering from the disease. In 1907 together with his brother Joseph, he was arrested by the police for a murder. Jack committed suicide while Joseph died in a prison before the pardon he had been granted [9].

\section{Symptoms}

There are concepts that the affiliation to an ethnic group, culture and environment predispose some people to characteristic personality clusters of a given region. Some of them are highly susceptible to psychiatric 
disorders. Over the years, new conceptions of national character, modal personality or basic personality type occurred. Examining different factors forming personality, such as ethnography, religion, pedagogical methods and some more, one can see some behavioral patterns. The goal of these analyses is investigation of the genesis of different mental disorders and the interaction between an individual and the collective [10].

Based on these observations, culture-bound disorders were differentiated. This term is defined as a collection of commonly unaccepted behaviors, specific for given regions, cultures, which may be diagnostic in DSMIV. Most of them are known as diseases and one of them is Wendigo psychosis [11]. Its symptoms are non-specific, but we can distinguish a set of qualities of potential patients. Furthermore, some people are diagnosed with two stages of disorder: the first of non-dangerous apathy and inactivity, and the second characterized by brutality and acts of cannibalism [3]. At the beginning, a patient often suffers from anorexia that may be a prodrome of anthropophagy. Insomnia, panic attacks, and fears are the next manifestations of the psychosis. There is a presumption that symptoms induction might be caused by the deficiency of group B vitamins (including thiamine), protein, fat, or ascorbic acid. A sudden cut of fat intake manifests as headaches and in a few weeks time may result in death. The inhabitants of subarctic regions are particularly vulnerable, because their fat intake is very high due to the energy requirements. Thiamine deficiency displays as gastric indigestion, restlessness, fatigue or malnutrition. Low blood sugar causes anxiety, depressive episode, neurosis, and in extreme cases psychosis [4]. Other considerations display the dysfunction as an extreme form of psychotic depression which is supported by the presence of hallucinations, anorexic states, inertia, dyssomnia, and finally the urge to taste human flesh [12]. The relevant dysfunctions of perception of the surrounding world are termed psychosis. It involves thinking process, awareness and stimulus perception disintegration. The afflicted people are confident of their imagination reality and proper functioning [13]. It leads to disappointment and inability to accept the reality. The initiation of Wendigo psychosis is associated with permanent loneliness during a winter season and chronic hunger, which may trigger the cannibalism urge [12].

\section{Epidemiology}

The epidemiologic data is not available. Wendigo psychosis, differentiated as culturally conditioned disorder, occurs among some ethnic groups. Its epidemiologic extent includes the Chippewa peoples, the Cree tribe and other Algonquian minorities. In 1960s 70 cases of Wendigo psychosis were noted. The ill had various degrees of symptoms intensity. When it comes to $63 \%$ of them (44 persons), they displayed acts of anthropophagy, and the remaining $37 \%$ (26 persons) recovered or were killed for fear of next attacks [4].

\section{Diagnosis and treatment}

Two Algonquian characteristics may be distinguished to have considerable impact on occurrence of Wendigo psychosis in this group. Primary, there is a total lack of struggle with cannibalism urge. Secondly, an unwitting following their needs without a conversation with the family. Anthropophagy impulses are attributed to supernatural forces. Because of it, the ill person may find the need irresistible. If there is any mental resistance, the diagnosis can be made upon frequent depressive episodes and the anorexic appearance. It is a result of the internal struggle with the animal instinct. The diagnosis of psychosis is mainly based on an irresistible urge and acts of cannibalism. Moreover, there are insomnia, hallucinations, melancholy, psychotic depression, and weight loss.

The shamans from the Indian tribes of the Northern America were responsible for curing the ill. Among 26 of diagnosed cases, 6 were cured by the natural methods. Three of them were successful. The other, very brutal measure to fight cannibalism was homicide. As many as 15 people were killed and 1 committed suicide. There were two necessary conditions to recover: a man needs to find some power to control his impulses, and the internal urge has to decrease [14].

Malnutrition and anorexia are often present. Another treatment attempt aims at proper nutrition. One of the Cree's stories tells about a woman who killed and consumed her husband and children, but eventually she was cured with a beverage from bear's liquid fat. After its intake, she vomited with ice and recovered. Wild rice with duck's meat or fat was also used. There are known cases of cured individuals after the emaciated people got regular meals. It is indicative of a huge influence of famine periods on the Wendigo psychosis and its symptoms [4]. Drinking boiling water and hot grease to warm the ice flowing in the ill's veins and heart is controversial [15].

In the 21st century the psychosis is treated mainly pharmacologically. The route of administration, the dose and the group of antipsychotic drugs are determined by a kind, a stage of disease and individual predispositions. At the beginning small doses are indicated. They may be increased according to the need to bring potential beneficial effect with minimal adverse reactions. The first-line therapy are benzodiazepines, and then the 2nd generation antipsychotics. The response appears within 10-14 days, but it should be administrated for at least 3-5 years, as it is critical, rebounding stage of the disease. If 
there is no improvement, the drugs should be changed as soon as possible [16].

\section{Summary}

Wendigo psychosis is a rare endemic disease, which is not available in regular literature and the data is very limited. Within the years, the dysfunction lost its significance and nowadays is presented as a part of beliefs, mythical legends and history. Investigating the history and symptoms of the illness, one may see a clearcut connection between the long hungry winter days and progressive psychosis or cannibalistic acts. Due to the civilization development the famine problem is not as critical as before, while the medicine progress enables effective psychiatric treatment. However, the use of drugs is associated with side effects, which may handicap the daily performance or even be life-threatening.

\section{Conflict of interest}

The authors have declared no conflict of interest.

\section{References:}

1. Horn, Kahntineta (March 14, 2013). "Boogie Men". mohawknationnews.com. Kahnawake: Mohawk Nation News. Retrieved August 24, 2018.

2. Brightman, Robert A. (1988). "The Windigo in the Material World" (PDF). Ethnohistory. 35 (4): 337-379. doi:10.2307/482140. JSTOR 482140.

3. Marano, L. (1982). Windigo psychosis: The anatomy of an emicetic confusion. Current Anthropology, 23(4), 385-412.

4. Rohrl, V. J. (1970). A nutritional factor in windigo psychosis. American Anthropologist, 72(1), 97-101.

5. Friedman, C.T.H. (1982). The so called hysteropsychoses: Latah, windigo and pibloktoq. In Extraordinary Disorders of Human Behavior

6. https://analepsis.files.wordpress.com/2015/02/windigo2.pdf
7. Lietz, M. (2016). Cannibalism in contact narratives and the evolution of the wendigo.

8. https://www.dictionary.com/browse/browser

9. Fiddler, Thomas; Stevens, James R. (1985). Killing the Shamen. Manotick, Ontario: Penumbra Press. ISBN 978-0920806814

10. Leighton $\mathrm{AH}$, Hughes JM PhD. Cultures as a Causative of Mental Disorder. Milbank Q. 2005;83(4):10.1111/j.14680009.2005.00424.x. doi:10.1111/j.1468-0009.2005.00424.x

11. Peter J. Guarnaccia , Ph.D., and Lloyd H. Rogler, Ph.D. 1999. Research on Culture-Bound Syndromes: New Directions, The American Journal of Psychiatry

12. Miller, Shelby (2016) "Sudden and Entire": Investigating the Accusation of Cannibalism in the Early Chippewa Tribes. History 489: Research Seminar

13. D. Semple, R. Smyth, J. Burns, R. Darjee, A. McIntosh 2007. Oksfordzki podręcznik psychiatrii. Redaktor Naukowy wydania polskiego prof. dr hab. n. med. Anna Grzywa. Copyright Oxford University Press. Wydanie I Lublin 2007, s. 198. Wydawnictwo Czelej, ISBN 978-83-60608-12-8.

14. Hay, T. H. (1971). The Windigo Psychosis: Psychodynamic, Cultural, and Social Factors in Aberrant Behavior 1. American anthropologist, 73(1), 1-19.

15. Leahy, R. The Devils of Cultural Conflict in Louise Erdrich's "Saint Marie".

16. Murphy, B. P., \& Brewer, W. J. (2011). Early intervention in psychosis: clinical aspects of treatment. Advances in psychiatric treatment, 17(6), 408-416.

\section{Corresponding author}

Kamil Leis

Faculty of Medicine, Ludwik Rydygier Collegium

Medicum in Bydgoszcz, Nicolaus

Copernicus University in Toruń, Poland

e-mail: kamil.leis13@gmail.com

Otrzymano: 23.07.2019

Zrecenzowano: 19.09.2019

Przyjęto do druku: 27.11.2019 